\title{
KNOWLEDGE REGARDING ADVERSE EFFECTS OF SELECTED COSMETIC PRODUCTS AMONG HIGHER SECONDARY LEVEL GIRL STUDENTS, CHITWAN \\ R Shrestha ${ }^{1}$, J Shakya ${ }^{1 *}$ \\ ${ }^{1}$ College of Nursing, Chitwan Medical College, Bharatpur, Chitwan \\ *Correspondence to: Ms. Jayalaxmi Shakya, College of Nursing, Chitwan Medical College, Bharatpur-10, Chitwan, Nepal
}

Email: shakyajaya@yahoo.com

\begin{abstract}
Cosmetics are substances used to enhance the appearance or odour of the human body. The age that females begin wearing makeup gets younger and younger with every new generation. A descriptive study design was used to find out knowledge regarding adverse effects of selected cosmetic products among higher secondary level girl students. A total 70 female students of Maiya Devi Girls' College, Bharatpur-10, Chitwan, 34 students of grade 11 and 36 students of grade 12 were selected by using probability simple random sampling lottery method. The result revealed that out of 70 respondents, $30 \%$ were of age 17 years, $51.4 \%$ were studying in grade $12.34 .3 \%$ respondents' had experienced adverse effects from using cosmetic products, $50 \%$ had experienced acne, almost all respondent's $98.6 \%$ got information of cosmetic products from television. Majority $82.9 \%$ of the respondents answered that cosmetic products are the substance use to enhance the appearance of body. Cent percent respondents' had knowledge that lipstick cause lip cancer, $88.6 \%$ had knowledge that kajal cause dry eye syndrome, $97.1 \%$ had knowledge that skin lightening cream and sunscreen cause skin cancer and perfumes cause skin irritation, $87.1 \%$ had knowledge that mascara cause eye irritation, and $98.6 \%$ had knowledge that nail polish cause cancer and reading expiry and manufacture date can prevent the occurrence of adverse effects. Majority $72.9 \%$ of respondents had average level of knowledge, $17.1 \%$ had low level of knowledge and $10.0 \%$ had high level of knowledge. Statistically there was significant association between level of knowledge of the respondents' regarding adverse effects of selected cosmetic products and grade of respondents $(p=0.044)$.
\end{abstract}

Key words: Adverse effect, Cosmetic product, Knowledge.

\section{INTRODUCTION}

Cosmetics are substances used to enhance the appearance or odor of the human body. They are generally mixtures of chemical compounds, some being derived from natural sources, many being synthetic. ${ }^{1}$

Cosmetic includes skin creams, lotions, perfumes, lipsticks, fingernail polishes, eye and face make-up products, permanent waves, hair dyes, toothpastes and deodorants. Fragrances and preservatives are the main ingredients in cosmetics. Fragrances are the most common cause of skin problems. More than 5,000 different kinds are used in products. Preservatives in cosmetics are the second most common cause of skin problems. They prevent bacteria and fungus from growing in the product and protect products from damage caused by air or light. $^{2}$

Assessment of lead in cosmetic products in Saudi Arabia found that lead contents were determined in 26 and eight different brands of lipsticks and eye shadows. Lead was detected in all the studied samples. The overall results indicate that lead in lipsticks and eye shadows are below the FDA lead limit as impurities and, thus, probably have no significant toxicological effects. Nevertheless, few brands had lead content above 20 PPM that might put consumers at the risk of lead poisoning. ${ }^{3}$ Sunscreen is widely acknowledged to protect 
against sunburn. However, there is some evidence that sunscreen use can contribute to negative health outcomes. Sunscreens are loaded with some seriously questionable ingredients that can induce adverse effects on your skin and body, (i.e., allergic reactions, hormone disruption, and premature aging), and might even increase your cancer risk. Oxybenzone, octinoxate, retinyl palmitate (vitamin a palmitate), paraben preservatives parabens (butyl-, ethyl-, methyl-, and propyl-) can induce allergic reactions, hormone disruption, developmental and reproductive toxicity. ${ }^{4}$ Skin lightening creams contain mainly two chemicals, hydroquinone or mercury. Most creams sold in the market are a dangerous cocktail of compounds like steroids, hydroquinone, and tretinoin, the long term use of which can lead to lethal health concerns likes permanent pigmentation, skin cancer, liver damage, mercury poisoning and others. There are plenty of cases of side effects especially among women in the age group of 20-30. Incidence of side effects among 14-15 years is worrying too. About 30 per cent of long term users report adverse effects. ${ }^{5}$

Kajal can have adverse effects on the eyes like conjunctivitis. Allergy, toxicity, meibomitis, stye, hordeolum, corneal ulcer, uveitis, glaucoma, dry eye syndrome, conjunctival discoloration. 6

Mascara induced milphosis, an etiological evaluation in Manglore found that a higher incidence of fall of eyelash and eye problem was observed in daily users of mascara. 7

Many of these chemicals are potential hormone disruptors that may increase cancer risk. Products commonly contain penetration enhancers to drive ingredients deeper into the skin. Studies find health problems in people exposed to common fragrance and sunscreen ingredients, including elevated risk for sperm damage, feminization of the male reproductive system, and low birth weight in girls. ${ }^{8}$

There was a trend of greater risk of systemic lupus erythematosus (SLS), with earlier age of initiation of lipstick use ( $<16$ years vs. never use) and with increased frequency of use (7 days/week vs. never use).$^{9}$

\section{MATERIALS AND METHODS}

A descriptive study was used to identify the knowledge regarding adverse effect of selected cosmetic products among higher secondary level girls' students. The populations of the present study included higher secondary level students of Maiya Devi Girls' College, Bharatpur 10, Chitwan studying at grade 11 and 12 , of health education stream and were selected by non-probability purposive sampling technique. Out of 100 students, 70 students were selected, 34 students of grade 11 and 36 students of grade 12 by using simple random sampling lottery method. Semi-structured self-administered questionnaire (SAQ) was used to measure the knowledge of respondents. The obtained data were analyzed according to the research questions and objectives of the study.

\section{RESULTS}

Table 1: Respondents' Socio-Demographic Characteristics $(n=70)$

\begin{tabular}{|c|c|c|}
\hline Variables & Frequency & Percentage \\
\hline \multicolumn{3}{|c|}{ Age in year } \\
\hline 15 & 2 & 2.9 \\
\hline 16 & 9 & 12.9 \\
\hline 17 & 21 & 30. \\
\hline 18 & 19 & 27.1 \\
\hline 19 & 19 & 27.1 \\
\hline \multicolumn{3}{|c|}{ Mean \pm SD $=(17.62+1.10)$} \\
\hline \multicolumn{3}{|l|}{ Grade } \\
\hline 11 & 34 & 48.6 \\
\hline 12 & 36 & 51.4 \\
\hline
\end{tabular}

Out of 70 respondents, 21 (30.0\%) respondents were of age 17 and mean age was 17.62 with standard deviation of 1.10. Regarding grade, 36 (51.4\%) respondents were studying in grade 12 and $34(48.6 \%)$ were studying in grade 1 . (Table 1 ) 
TABLE 2: Types, Duration of use and Brand of Cosmetic Products Used by the Respondents' $(n=70)$

\begin{tabular}{|l|l|l|}
\hline Variables & Frequency & $\begin{array}{l}\text { Percent- } \\
\text { age }\end{array}$ \\
\hline Types & & \\
\hline Lipsticks & 53 & 75.7 \\
\hline Kajal & 58 & 82.9 \\
\hline Sunscreen & 40 & 57.1 \\
\hline Sunscreen & 24 & 34.3 \\
\hline Skin lightening cream & 47 & 67.1 \\
\hline Nail polish & 52 & 74.3 \\
\hline Perfumes & 48 & 68.6 \\
\hline Duration of use & & \\
\hline Less than 1year & 16 & 22.9 \\
\hline (1-2) years & 21 & 30.0 \\
\hline More than 2 years & 33 & 47.1 \\
\hline Brands of cosmetic products use & \\
\hline Ponds & 40 & 58.0 \\
\hline Ponds & 15 & 21.7 \\
\hline Dove & 5 & 7.2 \\
\hline Fair \& Lovely & 15 & 21.7 \\
\hline Lakme & 12 & 17.4 \\
\hline Sonata & 33 & 47.8 \\
\hline Herbal & 1 & 1.4 \\
\hline Garnier & 6 & 8.7 \\
\hline Johnson's & 6 & 8.7 \\
\hline All respond's & (15 & \\
\hline
\end{tabular}

All 70 respondent's had habit of using some sorts of cosmetic products. Concerning the types of cosmetic products, majority 58 (82.9\%) of the respondents use kajal and 24 (34.3\%) use mascara. 33 (47.1\%) respondents were using cosmetic items for more than 2 years and 16 (22.9\%) respondents for less than 1 year. Similarly, 40 (58.9\%) respondents use pond's and $1(1.4 \%)$ respondent use herbal products. (Table 2)

All 70 respondent's had habit of using some sorts of cosmetic products. Concerning the types of cosmetic products, majority $58(82.9 \%)$ of the respondents use kajal and 24 (34.3\%) use mascara. 33 (47.1\%) respondents were using cosmetic items for more than 2 years and 16 (22.9\%) respondents for less than 1 year. Similarly, 40 (58.9\%) respondents use pond's and $1(1.4 \%)$ respondent use herbal products. (Table 2)

TABLE 3: Respondents' Experiencing Adverse Effects of Cosmetic Products

\begin{tabular}{|c|c|c|}
\hline Variables & Freq. & $\%$ \\
\hline \multicolumn{3}{|l|}{ Previous Experience $(n=70)$} \\
\hline Yes & 24 & 34.3 \\
\hline No & 46 & 65.7 \\
\hline \multicolumn{3}{|l|}{ Cosmetic product** $(n=24)$} \\
\hline Lipsticks & 2 & 8.7 \\
\hline Kajal & 5 & 21.7 \\
\hline Mascara & 2 & 8.7 \\
\hline Sunscreen & 4 & 17.4 \\
\hline Skin lightening cream & 13 & 56.5 \\
\hline Perfumes & 2 & 8.7 \\
\hline \multicolumn{3}{|l|}{ Adverse effects $* *(n=24)$} \\
\hline Allergies & 4 & 16.7 \\
\hline Dermatitis & 1 & 4.2 \\
\hline Rashes & 5 & 20.8 \\
\hline Acne & 12 & 50.0 \\
\hline Eye irritation & 8 & 33.3 \\
\hline Eczema & 1 & 4.2 \\
\hline
\end{tabular}

Table 3 shows that, out of 70 respondents, more than half $46(65.7 \%)$ of respondents had not experienced any adverse effects from the use of cosmetic products and $24(34.3 \%)$ respondents had experienced adverse effects from the use of cosmetic products.

Concerning the cosmetic products that had caused adverse effects out of 24 respondents, 13 (56.5\%) respondents were affected from skin lightening cream and 2 (8.7\%) respondents were affected from lipsticks, mascara and perfumes. Concerning the adverse effects, half $12(50.0 \%)$ of respondents had experienced acne and 1 (4.2\%) had experienced dermatitis and eczema. 
TABLE 4: Respondents' Knowledge regarding Cosmetic Products

$n=70$

\begin{tabular}{|l|l|l|}
\hline Meaning & Freq. & $\%$ \\
\hline $\begin{array}{l}\text { Substance use to enhance the } \\
\text { appearance of body* }\end{array}$ & 58 & 82.9 \\
\hline $\begin{array}{l}\text { Substance use to enhance the } \\
\text { appearance of clothes }\end{array}$ & 2 & 2.9 \\
\hline $\begin{array}{l}\text { Substance use to enhance the } \\
\text { appearance of gait }\end{array}$ & 2 & 2.9 \\
\hline $\begin{array}{l}\text { Substance use to enhance the } \\
\text { appearance of nature }\end{array}$ & 8 & 11.4 \\
\hline
\end{tabular}

*Correct response

Table 4 shows that, majority 58 (82.9\%) of the respondents answered cosmetic products are the substance use to enhance the appearance of the body and 2 (2.9\%) respondents answered cosmetic products are the substance use to enhance the appearance of clothes and gait.

TABLE 5: Respondents' Knowledge regarding Preventive Measures for Adverse Effects of Cosmetic Products

$n=70$

\begin{tabular}{|c|l|l|}
\hline Preventive measures** $^{* *}$ & Freq. & $\%$ \\
\hline $\begin{array}{l}\text { Always read label* } \\
\text { Read expiry and manufacture } \\
\text { date* }\end{array}$ & 67 & 95.7 \\
\hline Prevent contamination* $^{*}$ & 37 & 98.6 \\
\hline Daily wash applied product* & 43 & 61.4 \\
\hline Share the cosmetic products & 13 & 18.6 \\
\hline Always test before use* & 23 & 32.9 \\
\hline Use cosmetic testers & 7 & 10.0 \\
\hline$* *$ Multiple response & ${ }^{*}$ Correct response
\end{tabular}

Table 5 shows that, near to cent percent 69 (98.6\%) of respondents answered the adverse effects of the cosmetic products can be prevented by reading expiry and manufacture date and $7(10.0 \%)$ answered by using cosmetic testers.
TABLE 6: Overall Distribution of Knowledge Scores of Different Variables

\begin{tabular}{|l|c|c|c|c|}
\hline $\begin{array}{l}\text { Knowledge } \\
\text { Variables }\end{array}$ & Mean \pm SD & $\begin{array}{c}\text { Mean } \\
\%\end{array}$ & $\begin{array}{c}\text { Maximum } \\
\text { Score } \\
\text { Obtained }\end{array}$ & Range \\
\hline $\begin{array}{l}\text { Concept of } \\
\text { cosmetic } \\
\text { products }\end{array}$ & $0.82 \pm 0.37$ & 82.85 & 1 & $0-1$ \\
\hline $\begin{array}{l}\text { Adverse } \\
\text { effects of } \\
\text { lipticks }\end{array}$ & $2.41 \pm 0.64$ & 60.35 & 4 & $0-4$ \\
\hline $\begin{array}{l}\text { Adverse } \\
\text { effects of } \\
\text { kajal }\end{array}$ & $2.94 \pm 0.58$ & 73.57 & 4 & $0-4$ \\
\hline $\begin{array}{l}\text { Adverse ef- } \\
\text { fects of skin } \\
\text { lightening } \\
\text { cream }\end{array}$ & $3.31 \pm 0.60$ & 82.85 & 4 & $0-4$ \\
\hline $\begin{array}{l}\text { Adverse } \\
\text { effects of } \\
\text { perfumes }\end{array}$ & $2.67 \pm 0.73$ & 66.78 & 4 & $0-4$ \\
\hline $\begin{array}{l}\text { Adverse } \\
\text { effects of } \\
\text { mascara }\end{array}$ & $3.28 \pm 0.78$ & 82.14 & 4 & $0-4$ \\
\hline $\begin{array}{l}\text { Adverse } \\
\text { effects of } \\
\text { sunscreen }\end{array}$ & $2.95 \pm 0.75$ & 73.92 & 4 & $0-4$ \\
\hline $\begin{array}{l}\text { Adverse ef- } \\
\text { fects of nail } \\
\text { polish }\end{array}$ & $2.65 \pm 0.63$ & 66.42 & 4 & $0-4$ \\
\hline $\begin{array}{l}\text { Preventive } \\
\text { measures }\end{array}$ & $3.41 \pm 0.64$ & 85.35 & 5 & $0-5$ \\
\hline
\end{tabular}

Table 6 shows that, out of 70 respondents majority $85.35 \%$ of knowledge score was obtained in prevention measures of adverse effects of cosmetic products with mean and standard deviation $3.41 \pm$ 0.64 and $60.35 \%$ of knowledge score was obtained in adverse effects of lipsticks with mean and standard deviation $2.41 \pm 0.64$. 
TABLE 7: Respondent's Level of Knowledge regarding Adverse Effects of Selected Cosmetic Products $(n=70)$

\begin{tabular}{|l|l|l|}
\hline Level of Knowledge & Frequency & Percentage \\
\hline Good $(80 \%-100 \%)$ & 7 & 10.0 \\
\hline Moderate $(60 \%-79 \%)$ & 51 & 72.9 \\
\hline Poor $(<60 \%)$ & 12 & 17.1 \\
\hline
\end{tabular}

Table7 shows that 51 (72.9\%) respondent's had average knowledge regarding adverse effects of selected cosmetic products followed by 12 (17.1\%) respondent's had low level of knowledge and 7 (10.0\%) had high level of knowledge regarding adverse effects of selected cosmetic products. Moderate and good level of knowledge was merged together as moderate level of knowledge to see the significance of the study.

TABLE 8: Association between Respondents' Level of Knowledge regarding Adverse Effects of Selected Cosmetic Products and Selected Variables $(n=70)$

\begin{tabular}{|c|c|c|c|c|}
\hline \multirow[b]{2}{*}{ Variables } & \multicolumn{2}{|c|}{ Level of Knowledge } & \multirow[b]{2}{*}{$x^{2}$} & \multirow{2}{*}{$\begin{array}{c}\text { p } \\
\text { value }\end{array}$} \\
\hline & Low\% & Moderate\% & & \\
\hline \multicolumn{5}{|l|}{ Age } \\
\hline $15-17$ & 7 (21.9) & $25(78.1)$ & & \\
\hline $18-19$ & $5(13.2)$ & $33(86.8)$ & 0.929 & 0.335 \\
\hline \multicolumn{5}{|l|}{ Grade } \\
\hline 11 & $9(26.5)$ & $25(73.5)$ & & \\
\hline 12 & $3(8.3)$ & 33 (91.7) & 4.050 & $0.044^{*}$ \\
\hline \multicolumn{5}{|c|}{ Duration of use } \\
\hline $\begin{array}{l}1-2 \\
\text { years }\end{array}$ & $5(13.5)$ & $32(86.5)$ & & \\
\hline $\begin{array}{l}3-5 \\
\text { years }\end{array}$ & $7(21.2)$ & $26(78.8)$ & 0.728 & 0.394 \\
\hline \multicolumn{5}{|c|}{ Previous Experience } \\
\hline Yes & $4(16.7)$ & $20(83.3)$ & & \\
\hline No & $8(17.4)$ & $38(82.6)$ & 0.006 & 0.939 \\
\hline
\end{tabular}

*Significance level at 0.05
Table 8 shows that the level of knowledge of the respondent's regarding adverse effects of selected cosmetic products is statistically significant with the grade $(p=0.044)$.

However, there is no significant association between the level of knowledge and selected variables such as age $(p=0.335)$, duration of use $(p=0.394)$ and previous experience (0.939)

\section{DISCUSSION}

Concerning the habit of using cosmetic products, all $(100.0 \%)$ respondents had the habit of using cosmetic products which correlates well with the study conducted by Dibaba et al. (2013) which revealed that $97.8 \%$ of respondents had the habit of using cosmetic products. ${ }^{10}$

Concerning the duration of use of cosmetic products this study revealed that $30.0 \%$ respondents had $1-2$ years of experience. The finding is supported by the study conducted by Kyung (2012) which revealed that $20 \%$ of respondents had 1-2 years' experiences. ${ }^{11}$

Regarding the information of cosmetic products, this study reveals that majority $82.9 \%$ of respondents had knowledge that cosmetic products are the substance use to enhance the appearance of the body.

Regarding the harmful chemical of lipstick and its adverse effects, this study revealed that 34.3\% respondents had knowledge that lead is the harmful chemical found in lipstick and $100.0 \%$ respondent's had knowledge that lipstick cause lip cancer.

Concerning the harmful chemical found in perfumes and its adverse effects, this study revealed that $25.7 \%$ respondents had knowledge that acetaldehyde is the harmful chemical found in perfumes and $97.1 \%$ respondents had knowledge that perfumes cause skin irritation. 


\section{CONCLUSION}

The conclusions are based on the findings of the study. The study reveals that majority of respondents had average knowledge. Majority $85.35 \%$ of knowledge score was obtained in preventive measures of adverse effects of cosmetic products followed by $82.85 \%$ in concept of cosmetic products and adverse effects of skin lightening cream. The level of knowledge regarding adverse effects of selected cosmetic products is statistically significant with grade of the respondents $(p=0.044)$ i.e. who had higher level of education had better knowledge regarding adverse effects of selected cosmetic products in comparison to those who had lower level of education.

\section{REFERENCES}

1. Ullmann's Encyclopedia of Industrial Chemistry, (2005).

2. Read SI. (2004) Cosmetics and your health. Department of Dermatology, Georgetown University, Washington, D.C. Retrieved from http:// www.mbm.net.au/health/cosmetics/cosmetics.html

3. Al-Saleh I, Al-Enazi S, Shinwari N. Assessment of lead in cosmetic products. Regulatory Toxicology and Pharmacology 2009;54(2):105-

13. Retrieved from http://www.ncbi.nlm.nih.gov/ pubmed/19250956/

4. Loux R. (2012) 6 scary sunscreen Ingredients and 6 safe SPF products. Retrieved from http:// www. womenshealthmag.com/beauty/6-scarysunscreen-ingredients-and-6-safe-spf-products

5. Ravichandran N. (2013) Skin whitening creams can cause long-term damage. Retrieved from http:// www.dailymail.co.uk/indiahome/indianews/ article-2384456/Skin-whitening-creams-cause-longterm-damage-doctors-warn.html
6. dhawan S. (2009) Kajal - The harmful effects of kajal on the eyes. Retrieved from http:// eyecaredelhi.blogspot.com/2009/09/kajal-tehharmful-effects-of-kajal-on.html

7. Kadri R, Achar A, Tantry TP, Parameshwar D, Kudva A, Hegde S. Mascara Induced Milphosis, an Etiological Evaluation. International Journal of Trichology 2013;5(3):144-147. Retrieved from http:// www.ncbi.nlm.nih.gov/pmc/articles/PMC3927173

8. Environment Working Group (2010). Myths of Cosmetic Products. Retrieved from http:// www.ewg.org/enviroblog/2010/07/test-yourknowledge-cosmetics-safety-8-myths-debunked

9. Wang J, Kay AB, Fletcher J, Formica MK, McAlindon TE (2008). Is lipstick associated with the development of systemic lupus erythematosus (SLE)? Clinical

10. Dibaba H, Yadesa D, Legesse B, Shewamene Z, W Gerima B. Cosmetics Utilization Pattern and Related Adverse Reactions among Female University Students. International Journal of Pharmaceuticl Sciences and Research 2013;4(3):997-1004. Retrieved from http://www.ijpsr.com/ V4I3/13\%20Vol.\%204,\%20Issue $\% 203, \% 20$ March\%202013,\%20IJPSR-2135,\%20Paper\%2013.

11. Kyung SB. (2012) The impact of consumer innovativeness, attitude, and subjective norm on cosmetic buying behavior: evidence from APU female students. Retrieved from http://rcube. ritsumei.ac.jp/bitstream/10367/3929/1/52110003. C 2016, JCMC. All Rights Reserved 